Michael, K. D. (2006). What I Think I May Have Learned-Reflections on 50 Years of Teaching: An Interview with Michael Wertheimer. Teaching of Psychology, 33:4, pp. 280-287. (ISSN: 0098-6283) Version of record published by Taylor \& Francis.

DOI: 10.1207/s15328023top3304_9

\title{
What I Think I May Have Learned-Reflections on 50 Years of Teaching: An Interview with Michael Wertheimer Kurt D. Michael
}

\begin{abstract}
This is an interview with Michael Wertheimer, professor emeritus at the University of Colorado at Boulder, who has won awards for the teaching of psychology, for service, and for contributions to the history of psychology. After earning his BA (with high honors) from Swarthmore College and an MA in psychology from The Johns Hopkins University, he received his $\mathrm{PhD}$ in experimental psychology from Harvard University under the supervision of $\mathrm{S}$. S. Stevens and Edwin G. Boring. He also worked for 1 semester as a full-time research assistant to social psychologist Solomon E. Asch. His career at the University of Colorado at Boulder (after teaching for 3 years at Wesleyan University) included decades of service as director or codirector of the departmental honors program in psychology (1956 to 1993) as well as the presidency of Divisions 1 (General), 2 (Society for the Teaching of Psychology), 24 (Theoretical and Philosophical Psychology-twice), and 26 (History) of the American Psychological Association (APA) and of Psi Chi and the Rocky Mountain Psychological Association. Among his scholarly endeavors in the history of psychology is the preservation of his father's (Max Wertheimer) contributions to the development of Gestalt theory (King \& Wertheimer, 2005). He is the recipient of the Distinguished Teaching Award of the American Psychological Foundation and a Lifetime Achievement Award for Sustained, Outstanding, and Unusual Contributions to the History of Psychology from the APA's Division 26.
\end{abstract}




\section{ARTICLE}

Michael: When reflecting on some of your teachers and mentors, what exemplary behaviors did you notice? Which of these behaviors found their way into your teaching style and why?

Wertheimer: I don't believe I tried explicitly to imitate any of my own teachers - although perhaps I should have tried to do so. Among teachers who were impressive was my first-grade teacher in public elementary school, Miss Erich. I don't know how she did it, but she managed to get all the pupils in the class to cooperate in the effort to help a foreign student who spoke no English and who had just arrived in the United States from Germany (me) to learn the English language. Rather than having the students tease me or ridicule my halting attempts at the local language, she got them to correct me, advise me, and support me without making me embarrassed. It was a wonderful feat for which I am still grateful more than seven decades later.

At Swarthmore College, I had some excellent teachers. Both Solomon E. Asch and Robert B. MacLeod were very soft-spoken and gentle in their teaching styles, even diffident and self-effacing - but their enthusiastic fascination with the subject matter they were sharing with their classes and seminars was absolutely infectious. Hans Wallach had a teaching style that engaged students intensely: He would raise as a kind of puzzle some question or issue about which he actually knew a great deal in a kind of bumbling naive way and ask students for their opinions about the matter. This technique typically generated lively discussions. Usually it was only after he had managed to extract a correct perspective on the topic that it became evident to the students that he actually knew an immense amount about the matter at hand and that he had used his technique to get the students thinking about it before he shared his knowledge with them. There were other teachers as well who were highly effective, such as the prominent philosopher Maurice Mandelbaum.

Michael: How did your teachers at Hopkins compare?

Wertheimer: My teachers at Johns Hopkins were not as devoted to teaching as were my teachers at Swarthmore, 
where excellence in teaching was a major criterion for the hiring of faculty. One challenge that I found especially difficult was that at Swarthmore College I was taught that Gestalt theory was in and behaviorism and structuralism were out. At Hopkins, Gestalt was out and behaviorism in, and then at Harvard, neo-structuralism was the rage and faculty viewed both Gestalt and behaviorism as naive and wrong. So, what theoretical perspective could one endorse?

Michael: I understand that S. S. Stevens chaired your dissertation at Harvard and E. G. Boring was a member of your committee. Please describe your experience in working with these men.

Wertheimer: At Harvard, S. S. Stevens had a procedure in dealing with his graduate students that, although it was close to traumatic for his students at the time, did make it more likely that they would become independent scholars after they completed their graduate work. $\mathrm{He}$ asked for a dissertation proposal. He returned the one page proposal with the request that it be fleshed out. On receipt of the more detailed proposal, he said, in effect, "Okay, use the psychoacoustic lab for your work, and let me know when you have a draft of the dissertation." He never looked over my shoulder while I was designing apparatus, running participants, undertaking data analysis, or drafting the text. When he received a draft of the dissertation, he put together a committee consisting of himself, E. G. Boring, and William Verplanck. To my consternation, the committee decided that the dissertation was not ready for an oral exam. I asked each member of the committee what I had to do to make the dissertation acceptable. Stevens said my problem (which attacked a favorite theory of his) was not very good, but the methodology was excellent. Verplanck praised the problem but said the methodology was not very good, and Boring went along with his colleagues in deciding that the dissertation was not yet ready for an oral defense. I ran a few more experiments and revised the text, after which an oral defense was scheduled. To my great relief, I apparently passed with flying colors. I'm sure that this rather harrowing experience was at least in part responsible for my scholarly productivity during my early career (and throughout the rest of my career, too, for that matter). Stevens had launched me 
as an independent scholar.
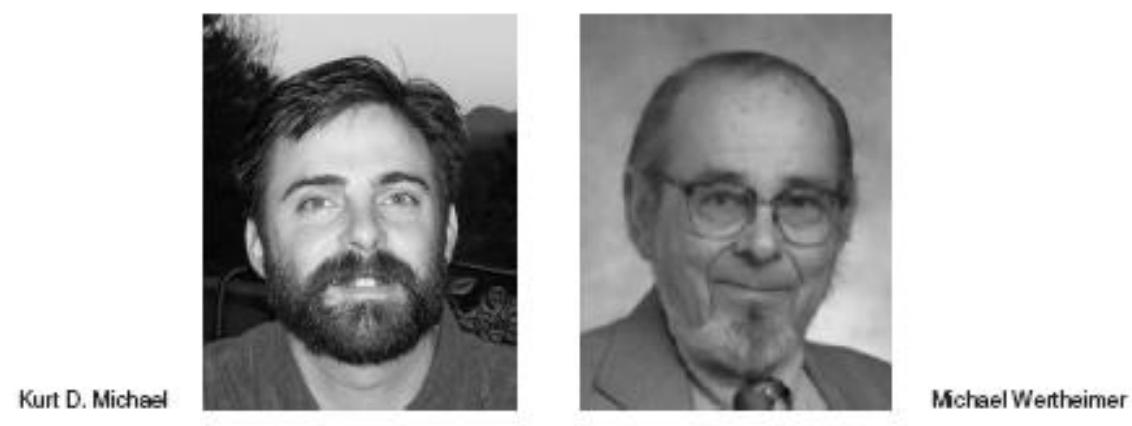

Michael: I realize that this next question is a broad one, but would you please describe how your father (and some of his Gestalt colleagues) influenced you and your career in psychology?

Wertheimer: Gestalt theory was part of my everyday life Fromm yearly childhood until my father died when I was 16 years old. Puzzles, creative thinking, and informed discussions animated the games my father played with his children and almost every dinner conversation. After my father died, his colleague, Wolfgang Köhler at Swarthmore College, in effect took me under his wing and facilitated my admittance to Swarthmore, where I majored successively in French literature, then linguistics, then philosophy, and finally in psychology. To overcome this - from Köhler's point of view-excessive concentration in humanities, he sent me to Johns Hopkins to receive a more thorough grounding in science. I am sure that the fact I was my father's son helped me get into prestigious schools and also helped me in obtaining good jobs. I am also sure that my father's encouragement of productive, "genuine" thinking played a major role in my lifelong love of intellectual activities and of the academic world.

Michael: What behaviors, if any, would you describe as unhelpful or harmful to becoming an effective teacher?

Wertheimer: My guess is that there are many different techniques that can be used in teaching - but that there are major individual differences among teachers in how well they can use various methods. Relatively few teachers might use lecturing effectively, whereas others 
might be rather poor lecturers but might be much more successful in getting through to students by raising questions or doing demonstrations and asking for extensive discussion. Occasionally teachers can get by with apparently enormous egos, but in my experience most of the time humility in a teacher tends to be far more effective.

Showing disrespect for either the students or the subject matter is one behavior that I believe is definitely harmful. Excessive citing of many different publications by date and author name during lectures is apt to lead students to believe that the teacher is more anxious to demonstrate erudition and command of a highly technical area rather than to help them to learn anything. I have one other observation: Being unreliable is to be avoided in every aspect of teaching. A teacher should not be late for class, go way over the time allotted to a class period, say something definitively that may not be true, or promise to do something and then not do it.

Michael: What do you consider to be your greatest challenges in teaching over the last 50 years?

Wertheimer: First, getting through to the students. The old lecture method, with a fascinated and (hopefully) fascinating speaker - whose knowledge is up-to-datesharing insights with eager and tuned-in students, doesn't seem to be working as well as it did 50 years ago. Many students don't seem to care about the material they are supposed to be studying or don't see its relevance to their lives. Some gimmicks sometimes help overcome this problem to some extent, but they do not work with every unengaged student (impersonating important figures from the past, using films, videos, demonstrations, role-playing, the Socratic method, dramatic actions such as the lecturer running up and down the classroom aisles or standing on the desk, etc.), and they are not appropriate in every class. I always tried to get every student excited about the subject matter in every class, but rarely if ever achieved that goal.

Second, keeping up with relevant developments in the subject matter being taught is challenging. Increases in information about all subfields of human knowledge have been occurring at an exponential rate. 
Back in the 1950s I read every issue of Psychological Abstracts from cover to cover, trying to keep up with developments in all areas of psychology, but several decades ago it had become impossible to keep up with important developments even in relatively small subfields of the discipline. The challenge became to present a reasonably up-to-date overview of the subject matter in a course, rather than one that was already hopelessly out of date.

A third challenge, which has become even more salient within the last decade or two, has been to try to master the enormous advances in communication technology that have revolutionized information flow. Creative use of computers in teaching has flourished, and teachers who do not make it a point to become computer-savvy find themselves at a disadvantage in helping modern students (who typically have grown up with computers) learn effectively.

Fourth, techniques for evaluating student progress have never been as reliable and valid as one would wish. The sophistication with which quizzes, tests, and exams are constructed does not seem to have increased much during my career, and I still do not know how to evaluate validly and efficiently how well a student knows a particular field. This difficulty inevitably resulted in major frustration because some students were being treated unfairly: receiving higher grades than they deserved or lower grades than they should have.

Finally, perhaps the greatest challenge is that there is never enough time to do well what you want to do. This point was particularly true for me in trying to help students write (and speak) effectively. Typically, I gave students opportunities to prepare several successive drafts of term papers, theses, dissertations, etcetera, providing them with repeated detailed editorial suggestions on their work - both substantive and stylistic or grammatical (including principles of paragraphing and even correction of spelling or punctuation errors). Although students received this practice with immense gratitude, there was never time enough to do it as much as I would have liked. Helping students get their written (and oral) work into a form in which it actually comes close to saying what they want it to say was always a 
challenging goal during my teaching career, a goal that I believe was far more important than teaching them about the current state of some subfield of knowledge. Skill in writing and speaking can be useful to anyone in any field throughout a lifetime.

However, the time challenge was not limited to the insufficient time available for feedback on written (and oral) student (and colleague) work. The balancing of legitimate claims for service, my scholarly work, family and friends, and teaching remained a challenge throughout my career. There simply was never time enough for everything I should have done or wanted to do, and to do it all as well as I possibly could.

Michael: Have your perceptions of students changed over the years?

Wertheimer: The student body has changed in many ways over the last half-century. Among other things, computers were just barely beginning to be developed in the middle of the 20th century, and computer know-how was a rare and special skill at that time. Nowadays almost all students are highly competent in using computersbut sometimes they are a bit uncritical in their assessment of the sources of information that they use. Not all students are aware of the difference between scholarly, reliable sources and those that are not.

Second, there has been a noticeable deterioration in students' language skills (reading, writing, and speaking). For example, term paper drafts and answers to essay questions on exams even from students who have obtained high grades on multiple-choice tests are often almost incoherent now. As I already noted, skills in oratory, written argumentation, even paragraphing have become worse, and many students have difficulty with spelling and punctuation. Whether these problems are due to the enormous rise in television viewing and in the uncritical use of e-mail and the Internet is hard to determine. Fifty years ago it was taken for granted that students would know how to write and speak coherently and effectively, but that expectation is unfortunately no longer the case. Students also appear to be less capable of obtaining knowledge from reading articles and books than they were several decades ago. 
Michael: Interpersonally speaking, have you noticed any systematic changes in the student body over time?

Wertheimer: Interpersonally, there seems to be less respect for faculty among students than there used to be. Forms of address toward faculty, for example, have become much less formal. Although the standard form of address was "Professor Michael" or "Dr. Michael" in the past, now it tends to be "Kurt" or "Hey, prof" or something of that ilk. Other examples of this trend include talking with another student while a faculty member is lecturing or leaving the classroom in the middle of the hour. Whereas such student behaviors were considered rude and unacceptable years ago, they have become more common in recent times.

Michael: Please describe some of your most satisfying experiences as a professor.

Wertheimer: By far the most rewarding experiences have been seeing students, especially ones who had some doubts about their abilities, succeed in coping with challenging intellectual tasks. On a more modest level, it was always satisfying when students who had murky or wrong ideas about a given topic obtained some insight and reorganized their way of thinking about that topic in such a way as to show an increase in intellectual sophistication. Seeing students actually learn has always been a source of great satisfaction for me. But most rewarding was the change in students' self-perceptions when they succeeded in intellectual tasks of which they previously thought they might be incapable. This phenomenon occurred quite often among candidates for departmental honors in psychology when they managed to defend their final theses competently. It also occurred occasionally among graduate students working on their theses or dissertations.

Recognition in the form of teaching awards was always pleasant, of course, but it paled in comparison with the receipt of unsolicited testimonials from former students who claimed that I had somehow made a positive difference in their lives. After all, that is what being a professor should be about.

Michael: If you could create a "top 10" list of best practices as a teacher and mentor, what would make the list? 
Wertheimer: That's a tough one. Among other things, I'm convinced that individual differences among teachers are great enough that practices that work for one faculty member in one setting may well not work for another faculty member or in another setting. Practices that may work well for one professor in a seminar may not work at all in a large lecture class by that same professor. Some professors could use a particular gimmick effectively in a large lecture class while in the hands of a colleague that same gimmick might fall flat. So it is hard to come up with a "top 10" list of practices. But a list of principles might be a bit easier to generate.

Michael: And what would that list include?

Wertheimer: First and foremost, respect students. Help them, even goad them, to achieve to the limits of their abilities. Encourage them, believe in them, never belittle them or make them feel stupid. Guide them to reliable sources of information, respect their confusions and questions, and help them formulate their assertions and queries so that they end up saying what they actually want them to say. Professors are charged with the responsibility of helping to shape students into intellectually competent citizens of this country and the world. Help them develop the skills and perspectives to think responsibly for themselves, to become truly liberal, liberated scholars.

Second, respect the subject matter that you are teaching: Be as up to date as possible about the most recent developments in the field, and, among other things, do not be dogmatic about taking a particular arbitrary position on controversial theoretical issues in the field. If you don't know the answer to some particular question, admit that you don't know the answerand try in a timely manner to find the answer to share with the class or with the student who raised the question. Using "yellowed notes" for the same class year after year is not acceptable in a field that is changing as rapidly as modern behavioral science is changing.

Third, the main goal of teaching and mentoring must be to help students develop and learn. Try to determine what the students' reasonable intellectual goals are and help them attain these goals. If the students' 
goals are unclear, mentor them in such a way as to help them formulate realistic goals.

Fourth, the teacher's aim must be to help students develop true insight and understanding about the subject matter being taught. Getting students to memorize material without comprehending it, making them able to "regurgitate" specific names, dates, technical terms, etcetera on tests and quizzes without fully understanding the material is insufficient. Respect students' questions, even if they appear to be poorly formulated. A student who dares to raise a question in a class is to be commended for doing so because chances are that other students have similar questions that they may be too timid to ask.

Fifth, the teacher needs to develop patience and realistic expectations. It may take multiple rephrasing, recasting, and review of the same material before a substantial subgroup of the students actually manages to "catch on" to some difficult material. Novice teachers sometimes assume that students will retain everything that has been assigned in readings for a course or everything that the teacher says in lectures - that is, of course, almost never the case. Lectures are notorious as being among the least effective teaching techniques, and student comprehension of material that they read is often quite poor. The teacher should make every effort to help students understand what they read and hearand retain it insightfully. This task is, admittedly, not an easy one. Nevertheless, teachers, although they should make clear to students that they have the highest expectations for student achievement, must remain realistic about what the students are actually likely to achieve.

There doubtless are many other "best" practices and principles for being a good teacher and mentor, but perhaps these five will do for now.

Michael: Looking over your record of service to the field of psychology is daunting. What do you consider to be some of your most important contributions in this regard?

Wertheimer: Among what I might consider my most important contributions in service is my involvement as director 
of the University of Colorado at Boulder's undergraduate honors program, with literally hundreds of candidates for departmental honors in psychology over the years. The individual mentoring of these students, many of whom later became prominent contributors to the discipline in academia or practice, was extremely rewarding to me.

Michael: Why—what did you find to be so satisfying about this work?

Wertheimer: Isn't that what being a teacher in an academic setting should be about? The most rewarding experience that a professor can have is seeing students succeed.

Michael: What other contributions did you find particularly rewarding?

Wertheimer: For about 40 years I have been continuously involved in one way or another with APA (as president of a division, representative to the APA Council of Representatives, member of various boards and committees, secretary or program chair of a division, etc.) and, to a lesser extent, with the Rocky Mountain Psychological Association and with Psi Chi. This extensive experience has made me feel reasonably comfortable with the process of getting major organizations to do the kinds of things that they should be doing. I know the ropes to some extent, making it possible for me to initiate or at least support endeavors that benefit psychology, psychologists, academia, and the culture and society that support the discipline. For example, years ago I helped the APA establish a clearinghouse for high school psychology that contained syllabi, a large collection of classroom demonstrations, reviews of textbooks, films, and other resources for the teaching of precollege psychology. I was also instrumental in the APA taking a formal position encouraging high school psychology to focus on teaching the discipline as a science. Further, a high school psychology text that emphasized the science of psychology that I translated from Swedish and adapted for the U.S. market did get published (Wertheimer, Bjorkman, Lundberg, \& Magnusson, 1971) but unfortunately did not find the market that I hoped it would. One recent success that felt really worthwhile was shepherding a proposal through the 
APA Council of Representatives to make an annual monetary subvention to the Archives of the History of American Psychology at the University of Akron, Ohio.

Another area, which may or may not really qualify as service, is the writing and editing I've done, including a number of textbooks and other volumes, several relevant to the history of psychology, that have enjoyed a fairly wide use. Among the books are my Brief History of Psychology (Wertheimer, 2000), which is now out in a fourth edition and which was translated into several foreign languages; the five-volume (soon to be six volume) set published jointly by the APA and by Erlbaum, Portraits of Pioneers in Psychology, each of which I coedited (Benjamin, Dewsbury, \& Wertheimer, 2006; Kimble, Boneau, \& Wertheimer, 1996; Kimble \& Wertheimer, 1998, 2000, 2003;

Kimble, Wertheimer, \& White, 1991); several introductory psychology texts of which I'm coauthor; and some more specialized works on the history of psychology (Viney \& Wertheimer, 1979), on methodology (Scott \& Wertheimer, 1962), and on perception (Beardslee\&Wertheimer, 1958). The total sales of volumes I've authored, coauthored, edited, or co-edited is now about half a million copies, which makes me feel pretty good (even though the royalty income from my books has been modest - one calculation resulted in the figure that I've probably earned between two and three cents per hour for all the time I've put into writing, translating, and editing books).

Various other service activities have also seemed worthwhile. Among these was the preparation, with Steve Davis, of an oral history of Psi Chi (Davis \& Wertheimer, 2000). This project involved edited standardized telephone interviews with all still living former (and current) members of the Psi Chi National Council. Another category is contacts with and support for foreign psychologists (e.g., in Germany, Sweden, Czechoslovakia). These contacts proved to be much appreciated, especially among beleaguered colleagues in East Germany when the Wall was still up. For that matter, the fact that my native language was German and my having studied French have been useful at international conventions and in several projects, including 
an English translation (based in part on my possession of a German-English and English-German dictionary from the same time), initiated by a German colleague, of a 1936 book, Laws of Seeing, by one of my father's last German students, Wolfgang Metzger (2006).

Yet another category involved mentoring various people new to APA governance or to positions on the faculty of major universities, usually members of groups underrepresented in psychology: ethnic minorities, women, gays, and lesbians, many of whom seemed lost and a bit overwhelmed by their new responsibilities and appreciated a shoulder to lean on or a person to consult about advice concerning priorities, standard practices, and realistic ways to get various things done.

Finally, I have campaigned against sexism in all venues, from classrooms through to APA boards, committees, staff, Council, and documents. One of the awards I have received of which I am proudest is a Gender Neutral Language Award from the Campus Women's Organization of the University of Colorado at Boulder in 1990. For decades I have insisted on the use of nonsexist language in papers, term papers, seminar presentations, dissertations, and theses, and have helped students (and colleagues) rephrase their prose so that it is not sexist. This goal is easier to achieve in English than in many other languages, but is, in my opinion, worth aiming for in all forms of communication.

Michael: What is your advice for new faculty about the extent to which they should engage in service activities?

Wertheimer: For practical reasons it is probably most important in the early stages of an academic career to do the kinds of things that will enhance the probability of achieving tenure. The requirements for tenure may vary a bit from institution to institution, but being a good, conscientious, and responsible teacher is of course among the top requirements. In many major universities, getting lucrative research grants and publishing extensively in top-level journals is another major criterion. Service is usually a distant third in the requirements for achieving tenure. Aside from enough service activity to show that one is a good departmental 
citizen and colleague, it is probably prudent to delay devoting an extensive amount of one's time and effort to service until after one has achieved tenure (and preferably a full professorship). Then one should try to find the time and energy for service activities that "really turn one on." There is a lot that one can achieve in service roles that can be tremendously rewarding - and very valuable to one's students, colleagues, discipline, community, and society.

Michael: Please elaborate on these rewards.

Wertheimer: It has been rewarding to be a part of developments such as the encouragement of the teaching of psychology as a science in high school by helping to draft - and pass - resolutions by the APA Council of Representatives and by preparing textbooks and demonstrations for that purpose. Publishing books and articles on and "for" the teaching of psychology has also been satisfying, as has mentoring appreciative younger colleagues and students in building their careers. Further, I have chaired most of the many boards and committees on which I have served, in part, I believe because I always tried to use the Quaker method of consensus rather than taking formal votes. Understanding the issues, respecting the views of colleagues, and aiming for collegiality have usually resulted in high morale and appropriate feelings of accomplishment on the part of almost everyone involved in such decision making.

Michael: The landscape of teaching psychology is evolving all the time. What current issues in the teaching of psychology do you consider to be the most important?

Wertheimer: For me, some of the most important issues include an increased emphasis on technology, the use of nontenure-track faculty, evaluation techniques, the rapidly changing nature of the discipline, and the lack of training in teaching.

Until 20 or 30 years ago, the teaching scene wasn't changing much. The typical teaching strategy, at least for beginning-level courses, was lecture, recitation or discussion sections, an occasional demonstration or film, possibly a weekly lab, and the use of a "body of organized 
knowledge" (i.e., a book).Now there's PowerPoint, elaborate videos, e-mail, and lots of technology far more sophisticated than the old chalk and blackboard (although students do not seem to be as adept in obtaining information and wisdom from reading books as they used to be). Nowadays a teacher must be savvy about all the new technological teaching aids, select among them and use them wisely and well — and not be overwhelmed or dominated by glitzy new gadgetry.

A second major development in a large number of colleges and universities is, for economic reasons and because of a glut of well-prepared psychologists and a dearth of well-paying tenure-track academic jobs, the exploitation of non-tenured colleagues. These colleagues typically have about twice the teaching load and only about half the income of tenured or tenure-track faculty or who are part time without benefitsand all of them with an uncertain future. Although in my experience many of these second-class faculty members are superb teachers and receive excellent ratings from their students, this practice seems to me to be short-changing the students and taking unfair advantage of the plight of underpaid instructors.

A third concern is that techniques for evaluating student progress (i.e., tests, quizzes, and examinations) not to mention methods for evaluating written work such as term papers - are typically of dubious reliability and validity. This concern is not often expressed in the literature on the teaching of psychology but is an important issue. Sophisticated evaluation technology, including the subtleties of responsible test construction, deserves more emphasis in the training of teachers than it currently receives, especially if the crucial task of assigning grades to students and their work is to be performed as fairly as possible.

Fourth, knowledge in the behavioral sciences is growing at an enormously rapid pace. It is difficult even for a conscientious instructor to remain fully up-to-date in a discipline whose subfields are changing so rapidly.

Finally, the typical new psychology instructor has had very little training in teaching. Most doctoral programs in academic psychology still emphasize research 
training and mastery of a rapidly changing small subfield of psychology and pay relatively little attention to the training of students for the teaching of psychology. True, there are exceptions; some doctoral programs do provide specific training in teaching and make experienced mentors available to graduate students who are assigned to teach lower level courses, but such practices are not as widespread as they probably should be. There is a large and useful literature on teaching to which most graduate students are not exposed, from Bill McKeachie's Teaching Tips (2006) to many articles in the Society for the Teaching of Psychology's journal, Teaching of Psychology.

Michael: Many faculty members struggle to balance their professional responsibilities across teaching, research, and service. How have you managed to maintain a balance over the years?

Wertheimer: I can't say that I really managed to maintain a balance across these three domains over the years. One truism that almost every faculty member learns very early is that there simply is not time enough to do everything one should do or wants to do and do it all well. This frustration is ubiquitous because most faculty members are convinced that anything worth doing at all is worth doing as well as one possibly can do it.

Obviously, the temporal demands of teaching have to be paramount (you cannot miss a class just because you are almost finished drafting a grant proposal and are eager to complete it), and certain service functions are also time-bound (department, board, and committee meetings and meetings with students are scheduled for particular times, and you have to make sure that you are there to attend them if you are supposed to be there). But even other service functions such as keeping one's posted office hours are specifically time-bound.

Of course, in terms of time allocation, teaching comes first, service is a close second, and research and scholarly work have to be fit into the time interstices remaining between them. Over the years, evenings, weekends, and "vacation times" were often devoted to scholarly activities for which there simply wasn't time in the normal work week. As Edwin G. Boring recommended 
many years ago, a responsible graduate student, beginning teacher, and mature faculty member should all count on an 80-hour week if they are to do justice to all of their legitimate aims and obligationsnot that I continued to devote 80 hours a week to professional activities throughout my entire career. I did put in enormous numbers of hours per week early during my career, but after the first decade or so it dropped to about 50 or 60 hours per week. The "balance" was dictated more by the realities of the job than by voluntary and deliberate decisions such as that in this coming week I will devote 9 hours to teaching, 11 hours to preparing for the teaching, 10 to service, 5 to reading, and 25 to research. The everyday work schedule rarely permits this kind of idealized planning. But if one is to make any scholarly contributions at all, then one simply must create the time for such endeavors despite the inflexible time demands of teaching and service.

Michael: What suggestions do you have for faculty members to have success in this regard?

Wertheimer: Probably all faculty members have to develop their own particular pattern, one with which they can be reasonably comfortable. Early in one's career, of course, one must establish one's ability as a teacher and, in many academic settings, one's credentials as a productive researcher. However, some institutions are explicit in saying, for example, that personnel decisions about faculty (raises, promotions, tenure) are based, for example, $40 \%$ on teaching, $40 \%$ on research, and $20 \%$ on service, but often these precise numbers have to be viewed with skepticism. At some major universities, the de facto numbers might be closer to $90 \%$ for scholarly work (largely measured by grant-getting record), $15 \%$ for teaching, and $-5 \%$ for service!

The artificial separation of these three activities into compartments that do not overlap, however, is not always appropriate or realistic. They can be combined to some extent, especially in the teaching of graduate seminars. For example, many of my publications are coauthored by graduate students (some of them by undergraduate students as well) and emerged as products from seminars. Hence, the activity that generated these articles (and book chapters) was related to teaching, resulted 
in published research, and clearly also involved service in that the students received extensive detailed feedback on how to engage in professional expository writing. Serving the goals of teaching and research can therefore sometimes be accomplished in the same activity, occasionally with service obligations being fulfilled as well. A creative teacher can often achieve several academic goals simultaneously, and that of course, is one of the heady attractions of the academic life. Although there are significant constraints, the world of academia affords many opportunities for creativity and flexibility. Being paid (modestly, in most cases) to pursue fascinating ideas wherever they might lead is and has been a most rewarding career.

Michael: Thank you sincerely for your time and energy in responding to these questions. On behalf of teachers of psychology everywhere, I am grateful for your thoughts and insights into these important issues with which we seem to grapple daily.

Wertheimer: Thank you so much for giving me the opportunity to share some of my impressions of the teaching profession, which I consider to be one of the most important roles in any society. I hope that some of these thoughts may be of use to some colleagues. I am flattered that you would take the trouble to interview me about these matters and feel humbled by the successes of many colleagues who I know are far more effective teachers than I ever was.

\section{Resources}

Beardslee, D. C., \& Wertheimer, M. (Eds.). (1958). Readings in perception. Princeton, NJ: Van Nostrand.

Benjamin, L. T., Jr., Dewsbury, D. A., \& Wertheimer, M. (Eds.). (2006). Portraits of pioneers in psychology (Vol. 6). Mahwah, NJ:

Lawrence Erlbaum Associates, Inc., and Washington, DC: American Psychological Association.

Davis, S. F.,\&Wertheimer, M. (2000). An oral history of Psi Chi: The National Honor Society in Psychology. Chattanooga, TN: Psi Chi:

The National Honor Society in Psychology. 
Kimble, G. A., Boneau, C. A., \& Wertheimer, M. (Eds.). (1996).

Portraits of pioneers in psychology (Vol. 2). Mahwah, NJ: Lawrence

Erlbaum Associates, Inc., and Washington, DC: American Psychological Association.

Kimble, G. A.,\&Wertheimer, M. (1998). Portraits of pioneers in psychology (Vol. 3). Mahwah, NJ: Lawrence Erlbaum Associates, Inc., and Washington, DC: American Psychological Association.

Kimble, G. A., \& Wertheimer, M. (2000). Portraits of pioneers in psychology (Vol. 4). Mahwah, NJ: Lawrence Erlbaum Associates, Inc., and Washington, DC: American Psychological Association.

Kimble, G. A.,\&Wertheimer, M. (2003). Portraits of pioneers in psychology (Vol. 5). Mahwah, NJ: Lawrence Erlbaum Associates, Inc., and Washington, DC: American Psychological Association.

Kimble, G. A., Wertheimer, M.,\&White, C. (Eds.). (1991). Portraits of pioneers in psychology. Hillsdale, NJ: Lawrence Erlbaum Associates, Inc., and Washington, DC: American Psychological Association.

King, D. B., \& Wertheimer, M. (2005). Max Wertheimer and Gestalt theory. New Brunswick, NJ: Transaction.

McKeachie, W. J., \& Svinicki, M. (2006). McKeachie's teaching tips: Strategies, research, and theory for college and university teachers (12th ed.). Boston: Houghton-Mifflin.

Metzger, W. (2006). Laws of seeing (L. Spillmann, S. Lehar, \& M. Wertheimer, Trans.). Cambridge, MA: MIT Press.

Scott, W. A.,\&Wertheimer, M. (1962). Introduction to psychological research. New York: Wiley.

Viney, W., \& Wertheimer, M. (1979). History of psychology: A guide to information sources. Detroit, MI: Gale.

Wertheimer, M. (2000). A brief history of psychology (4th ed.). Fort Worth, TX: Harcourt.

Wertheimer, M., Bjorkman, M., Lundberg, I., \& Magnusson, D. (1971). Psychology: A brief introduction. Glenview, IL: Scott Foresman. 


\section{Notes}

1. In September 2005, Michael Wertheimer was the keynote speaker at Appalachian State University Psychology Department's 4th annual Kulynych/Cline Teaching Festival, a yearly celebration of excellence in the teaching of psychology. Portions of this interview are based on that address.

2. Send correspondence to Kurt D. Michael, Psychology Department, Appalachian State University, PO Box 32109, 222 Joyce

Lawrence Lane, Boone, NC 28608; e-mail: michaelkd@ appstate.edu. 